\title{
Genetic study of familial cases of Alzheimer's disease
}

\author{
Anna Kowalska ${ }^{1 凶}$, Danuta Pruchnik-Wolińska ${ }^{2}$, Jolanta Florczak ${ }^{2}$, Renata \\ Modestowicz $^{2}$, Józef Szczech ${ }^{2}$, Wojciech Kozubski ${ }^{2}$, Grzegorz Rossa ${ }^{3}$ \\ and Mieczysław Wender ${ }^{4}$
}

\author{
${ }^{1}$ Institute of Human Genetics, Polish Academy of Sciences, Poznań, Poland; ${ }^{2}$ Department of \\ Neurology, University of Medical Sciences, Poznań, Poland; ${ }^{3}$ Provincial Hospital for \\ Neurological and Psychiatric Diseases, Cibórz, Poland; ${ }^{4}$ Neuroimmunological Unit, Medical \\ Research Center, Polish Academy of Sciences, Poznań, Poland
}

Received: 09 September, 2003; revised: 23 January, 2004; accepted: 29 January, 2004

Key words: Alzheimer's disease, amyloid precursor protein gene, dementia, mutation, neurodegeneration, presenilin 1 gene, presenilin 2 gene

\begin{abstract}
A small number (1-5\%) of Alzheimer's disease (AD) cases associated with the early-onset form of the disease (EOAD) appears to be transmitted as a pure genetic, autosomal dominant trait. To date, three genes responsible for familial EOAD have been identified in the human genome: amyloid precursor protein $(A P P)$, presenilin 1 (PS1), and presenilin 2 (PS2). Mutations in these genes account for a significant fraction (18 to 50\%) of familial cases of early onset $\mathrm{AD}$. The mutations affect APP processing causing increased production of the toxic $A \beta 42$ peptide. According to the "amyloid cascade hypothesis", aggregation of the A $\beta 42$ peptide in brain is a primary event in $\mathrm{AD}$ pathogenesis. In our study of twenty $\mathrm{AD}$ patients with a positive family history of dementia, $15 \%$ ( 3 of 20 ) of the cases could be explained by coding sequence mutations in the PS1 gene. Although a frequency of PS1 mutations is less than $2 \%$ in the whole population of AD patients, their detection has a significant diagnostic value for both genetic counseling and treatment in families with $A D$.
\end{abstract}

Alzheimer's disease (AD) is a progressive neurodegenerative disorder characterized by devastating memory loss and personality changes. The major pathological hallmarks of
$\mathrm{AD}$ are accumulation of senile plaques throughout the cortex, aggregation of highly phosphorylated tau protein (NFT) in neurons and death of selected populations of neuronal

\footnotetext{
${ }^{凶}$ Address for correspondence: Dr. Anna Kowalska, Institute of Human Genetics, Polish Academy of Sciences, Strzeszyńska 32, 60-479 Poznań, Poland; tel. (48 61) 8233211 ext. 217; fax (48 61) 823 3235; e-mail: annkowal@rose.man.poznan.pl
}

Abbreviations: AD, Alzheimer's disease; APOE, apolipoprotein E; APP, amyloid precursor protein; EOAD, early-onest Alzheimer's disease; LOAD, late-onset AD; PS, presenilin; TM, transmembrane. 
cells. From genetic studies of families with autosomal dominant pattern of disease inheritance, three genes responsible for familial early onset $\mathrm{AD}$ (EOAD; first symptoms before 65 years of age) have been identified in the human genome: amyloid precursor protein $(A P P)$ on chromosome 21 at 21q21.1 (Tanzi et al., 1987), presenilin 1 (PS1) on chromosome 14 at $14 \mathrm{q} 24.3$ (Sherrington et al., 1995) and presenilin 2 (PS2) on chromosome 1 at 1q42.1 (Levy-Lahad et al., 1995). Moreover, the Apolipoprotein E (APOE) gene polymorphism was found as a strong susceptibility factor for AD (Saunders et al., 1993). Genetic analyses revealed that carriers of the $A P O E^{*} 4$ allele are at a higher risk of the disease than $A P O E^{*} 4$ non-carriers. The APP gene encodes a polypeptide of up to 770 amino acids which is probably involved in nuclear signaling (Selkoe, 1998). According to the "amyloid cascade hypothesis”, abnormalities of APP metabolism with subsequent $\beta$-amyloid (A $\beta$ ) generation play a central role in the pathogenesis of AD (Hardy \& Higgins, 1992). APP is processed by three proteases, named $\alpha$-, $\beta$-, and $\gamma$-secretases. A series of endoproteolytic cleavages of APP leads to the formation of non-amyloidogenic (the $\mathrm{A} \beta 40$ fragment generated by $\alpha$-secretase) or amyloidogenic (the $\mathrm{A} \beta 42$ peptide generated by $\beta$ - and $\gamma$-secretases) products. By contrast to $\mathrm{A} \beta 40$, $\mathrm{A} \beta 42$ has a greater tendency to form fibrillary $\beta$-amyloid deposits. The deposition of "seeding” $\mathrm{A} \beta 42$ accelerates $\mathrm{A} \beta 40$ accumulation and stimulates a cascade of processes leading to formation of plaques and neurofibrillary tangles (NFTs) with subsequent neuron death (Jarret \& Lansbury, 1993). The presenilin genes (PS) encode multipass membrane proteins, named presenilins (PS) which have been found in the nuclear membrane, endoplasmic reticulum, and the Golgi (Kovacs et al., 1996). The most known topological model of PS suggests eight transmembrane domains. PS1 and PS2 display a high homology sharing $67 \%$ of aminoacid sequence. Their transmembrane domains are even more similar, with an identity of $84 \%$ (Levy-Lahad et al., 1995). The presenilins are involved in the Notch and Wnt/ $\beta$-catenin signaling pathways (Levitan \& Greenwald, 1995). The ps1 is necessary for normal neurogenesis and survival and localizes to synaptic membranes and neurite growth cones (Soriano et al., 2001). Moreover, presenilins have been suggested to regulate apoptosis and the unfolded protein stress response (Niwa et al., 1999).

Pathogenic mutations within the APP and $P S$ genes account for up to $50 \%$ of familial EOAD cases. If one of the genes is mutated, the mutated protein leads to development of $\mathrm{AD}$ with a penetrance close to $100 \%$. So far, 20 mutations in the APP gene, 124 mutations in the $P S 1$ gene, and 8 mutations in the PS2 gene have been described worldwide. Most of the mutations are substitutions. Only a couple of deletions and insertions and two splicing defect mutations have been reported in the PS1 gene (Cruts et al., 1998). All APP mutations are clustered near the $\alpha$-, $\beta$-, or $\gamma$-secretase cleavage sites, demonstrating that they have a direct effect on APP processing and $\mathrm{A} \beta$ formation. A majority of them affect the activity of secretases causing an increased production of $\mathrm{A} \beta 42$ (Citron et al., 1992). Recent data show that $P S$ mutations also affect APP processing causing overproduction of the amyloidogenic and toxic $\mathrm{A} \beta 42$ peptide (Selkoe \& Podlisny, 2002). However, the exact role of presenilins in the cleavage of APP is unclear, although multiple lines of evidence suggest that these proteins are essential for $\gamma$-secretase activity (Kowalska \& Wender, 1998; Kowalska, 2003). Presenilins probably constitute the active site of a large protein complex which is responsible for the $\gamma$-secretase processing of the APP protein. PS mutations may disturb protein interactions in the complex through subtle conformational alterations (Esler \& Wolfe, 2001).

To contribute to our knowledge of the genetic background of Alzheimer's disease in Poland, we performed a mutation analysis of 
the APP, PS1 and PS2 genes in patients with Alzheimer's disease from families in which dementia was transmitted as a genetic autosomal dominant trait.

\section{MATERIAL AND METHODS}

A sample of twenty patients with $\mathrm{AD}$ including 6 patients with EOAD (age of onset below 65 years), 6 patients with LOAD (late onset $\mathrm{AD}$ at or over 65 years) from families with autosomal dominant mode of dementia inheritance (at least three patients with dementia in at least two generations), and 8 patients with familial EOAD (at least two demented persons in patient's family) was screened for $A P P$ and $P S$ mutations. The ages of the patients ranged from 30 to 94 years. The diagnosis, based on NINCDS-ADRDA (National Institute of Neurological and Communicative Disorders and Stroke and the Alzheimer's Disease and Related Disorders Association) work group guidelines (McKhann et al., 1984), was made by clinical evaluations in the majority of cases including a CT scan and exclusion of other causes of dementia. We also examined 48 healthy control subjects from Poznań region. The study was approved by the Medical Ethical Committee of the University of Medical Sciences in Poznań.

Blood samples were collected and genomic DNA was extracted with the QIAmp Blood Kit (Qiagen). Screening for mutations was carried out by the PCR-SSCP approach (Kowalska et al., 1997). Ten coding exons 3-12 of the PS1 and PS2 genes were amplified separately using primers designed to the flanking intronic sequences according to Kamimura et al. (1998). PCR conditions were $94^{\circ} \mathrm{C}$ for $10 \mathrm{~min}$; 30 cycles of $94^{\circ} \mathrm{C}$ for $1 \mathrm{~min}$, $54-69^{\circ} \mathrm{C}$ for $1 \mathrm{~min}$, and $72^{\circ} \mathrm{C}$ for $2 \mathrm{~min}$; and a final 10 -min extension at $72^{\circ} \mathrm{C}$. The reaction volume was $50 \mu \mathrm{l}$ containing $500 \mathrm{ng}$ of human DNA template, $50 \mathrm{pM}$ primers, $200 \mu \mathrm{M}$ dNTPs, $1.5 \mathrm{mM} \mathrm{MgCl}, 10 \mathrm{mM}$ Tris/ $\mathrm{HCl} \mathrm{pH}$ 8.2, $50 \mathrm{mM} \mathrm{KCl}$, and 1-2 units of Taq poly- merase (TaKaRa). The PCR of exons 16 and 17 of the $A P P$ gene, encoding the $\beta$-amyloid fragment, was performed as described by Tanzi et al. (1992). A $5 \mu \mathrm{l}$ aliquot of each PCR product was checked on $6 \%$ polyacrylamide gel. For SSCP, $2 \mu \mathrm{l}$ a PCR product was applied to the GenePhor Electrophoresis system (Pharmacia). Gels were run for $100 \mathrm{~min}$ at $15^{\circ} \mathrm{C}$ at running conditions: $600 \mathrm{~V}, 50 \mathrm{~mA}$, $30 \mathrm{~W}$. Bands were then visualized using the DNA silver staining kit (Pharmacia) in a Hoefer automated gel stainer. The exons presenting band shifts were subsequently subcloned into pAT vector (Invitrogen) and analyzed by DNA sequencing using the ABI PRISM Dye Terminator Cycle Sequencing Core Kit and the ABI 377 automated DNA sequencer (Applied Biosystems, Foster City, CA, U.S.A.) according to the supplier's protocols. Apolipoprotein $E$ genotyping was performed as described earlier (Wenham et al., 1991; Kowalska et al., 1998).

\section{RESULTS}

Screening for mutations in the APP, PS1, and PS2 genes was performed for 20 familial $\mathrm{EOAD} / \mathrm{LOAD}$ cases. In addition, $A P O E$ genotyping was carried out. The results are summarized in Table 1. The following missense mutations in the PS1 gene: A246E in exon 7, P267L in exon 8, and L424R in exon 12 were found in patients from the families with autosomal dominant EOAD (ADEOAD) (Fig. 1). No mutations were found in 48 control individuals. The co-segregation of the mutations with $\mathrm{AD}$ was confirmed in the two ADEOAD pedigrees in which additional family members were available for genetic study (Fig. 1). Only one polymorphism, the $\mathrm{A} \rightarrow \mathrm{C}$ transversion, was found at position +16 in intron 8 of the $P S 1$ gene, identical to that first reported by Wragg et al. (1996). No mutations were found in the PS2 gene. One polymorphism, the $\mathrm{T} \rightarrow \mathrm{C}$ transition, was observed in exon 4 at codon H87 of the PS2 gene. We did 
not detect any mutations in exons 16 and 17 of the APP gene. Therefore, we excluded both $P S 2$ and $A P P$ mutations as the cause of $\mathrm{AD}$ in the analyzed cases. APOE genotyping revealed that patients carrying at least one $A P O E^{*} 4$ allele constituted $40 \%$ (8 of 20 ) of the cohort. Among the 20 patients, four (20\%) were homozygotes and another four heterozygotes for the $A P O E^{*} 4$ allele. The two out of to the TM VII (exon 11). The mutations are predicted to interfere with the $\alpha$-helical structure of TM II or the proteolytic processing of presenilins occurring in HL VI. The PS1 mutations found in this study were also located in functional domains of the protein: TM VI (A246E in exon 7), HL VI (P267L in exon 8), and TM VII (L424R in exon 12) (Fig. 2). The onset age in the PS1 mutation cases varied

Table 1. Analysis of PS1, PS2, APP and APOE genes in a cohort of familial EOAD/ LOAD cases

\begin{tabular}{lccccc}
\hline Patient & $\begin{array}{c}\text { Age of } \\
\text { onset }\end{array}$ & PS1 & PS2 & APP & APOE \\
\hline 1. ADEOAD & 30 & L424R & - & - & $3 / 3$ \\
2. ADEOAD & 52 & A246E & - & - & $3 / 4$ \\
3. ADEOAD & 56 & P267L & - & - & $3 / 3$ \\
4. ADEOAD & 41 & - & - & - & $3 / 3$ \\
5. ADEOAD & 45 & - & - & - & $4 / 4$ \\
6. ADEOAD & 46 & - & - & - & $3 / 4$ \\
7. ADLOAD & 66 & - & - & - & $4 / 4$ \\
8. ADLOAD & 72 & - & - & - & $4 / 4$ \\
9. ADLOAD & 76 & - & - & - & $3 / 4$ \\
10. ADLOAD & 78 & - & - & - & $4 / 4$ \\
11. ADLOAD & 90 & - & - & - & $3 / 4$ \\
12. ADLOAD & 94 & - & - & - & $2 / 3$ \\
13. FAD & 42 & - & - & - & $3 / 3$ \\
14. FAD & 46 & - & - & - & $3 / 3$ \\
15. FAD & 50 & - & - & - & $3 / 3$ \\
16. FAD & 56 & - & - & - & $3 / 3$ \\
17. FAD & 58 & - & - & - & $3 / 3$ \\
18. FAD & 58 & - & - & - & $3 / 3$ \\
19. FAD & 59 & - & - & - & $3 / 3$ \\
20. FAD & 60 & - & - & - & $3 / 3$ \\
& & $3 / 20$ & $0 / 20$ & $0 / 20$ & \\
\hline
\end{tabular}

ADEOAD, autosomal dominant early-onset Alzheimer's disease; ADLOAD, autosomal dominant late-onset Alzheimer's disease; FAD, familial Alzheimer's disease

three patients with PS1 mutations were homozygotes for the APOE* 3 allele (Table 1 ).

\section{DISCUSSION}

Most presenilin mutations reported so far were identified in or close to the highly conserved transmembrane (TM) regions of the proteins and in the large hydrophilic loop (HL VI) occurring after TM VI. There are two clusters of mutations in the PS1 gene. One of them is in the TM II domain encoded by exon 8 while the other extends from the TM VI domain (exons 7/8) through HL VI (exons 8/11) from 30 years (L424R) to 52 years (A246E) and 56 years (P267L). It was suggested that the age of $\mathrm{AD}$ onset could be determined by the nature of the mutation and its position in the gene (Cruts \& Van Broeckhoven, 1998). Another possibility is that the onset age is modulated by additional genetic and/or environmental factors influencing expression of PS1 mutations, for example the APOE gene variability. However, there is no clear evidence for an effect of $A P O E$ genotype on the onset age in patients with PS1 mutations. Two out of three PS1 patients presented here had the APOE3/3 genotype, suggesting an absence of any correlation. The prevalence of 

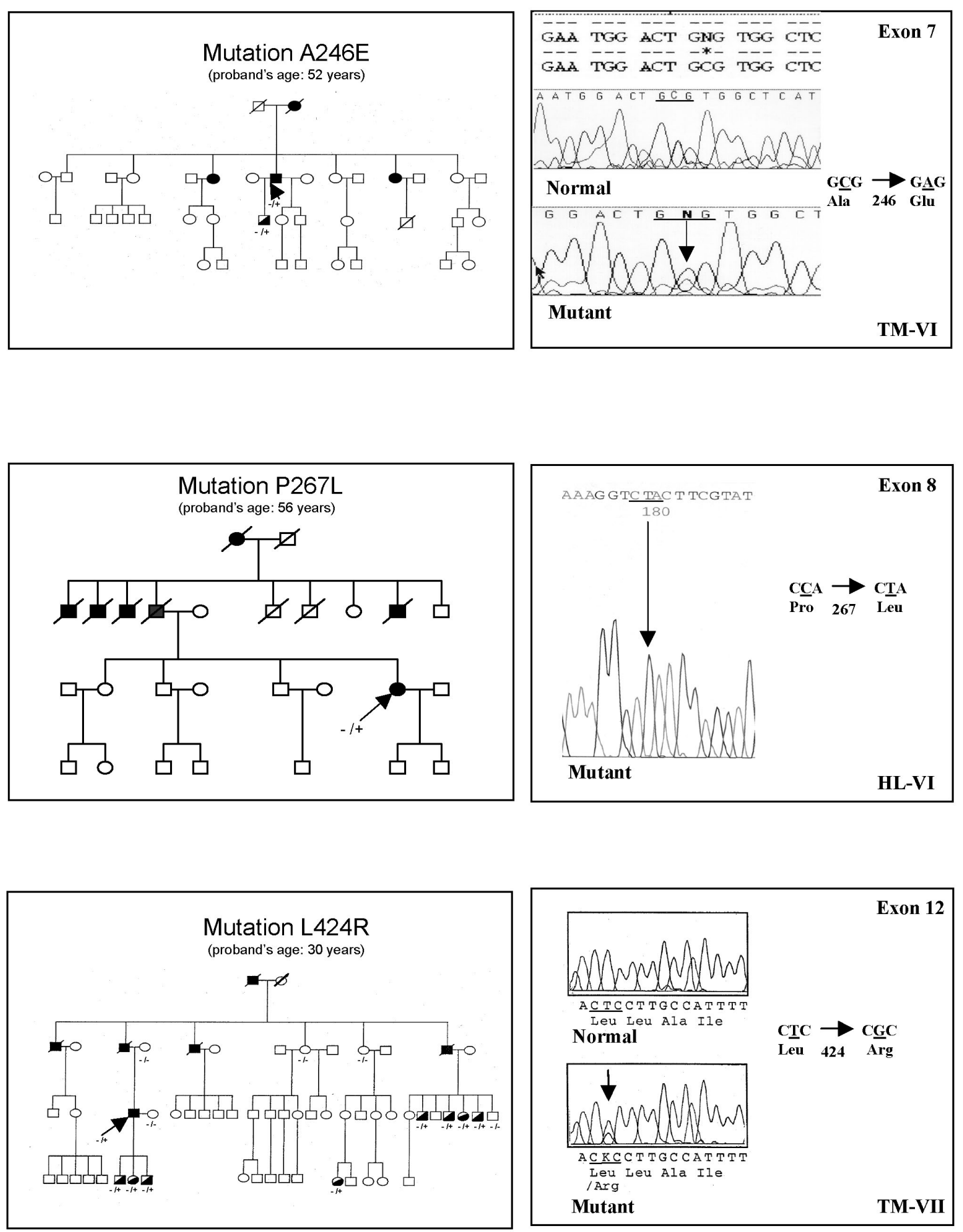

Figure 1. The PS1 gene mutations identified in three unrelated families with autosomal dominant early-onset Alzheimer's disease.

PS1 mutations among AD patients depends on criteria used to select the patients and varies from 18\% (Cruts et al., 1998) to the over $50 \%$ (Campion et al., 1999) in presenile autosomal dominant Alzheimer's disease. Screening for mutations in a referral-based cohort of 414 patients with a high index of suspicion of familial AD revealed PS1 mutations in $11 \%$ of cases (Rogaeva et al., 2001). In the current study the frequency of PS1 mutations was $15 \%(3 / 20)$ in the whole sample of familial $\mathrm{AD}$ cases, or $50 \%$ (3/6) if the analysis was restricted to the EOAD families with a clear autosomal dominant mode of inheri- 


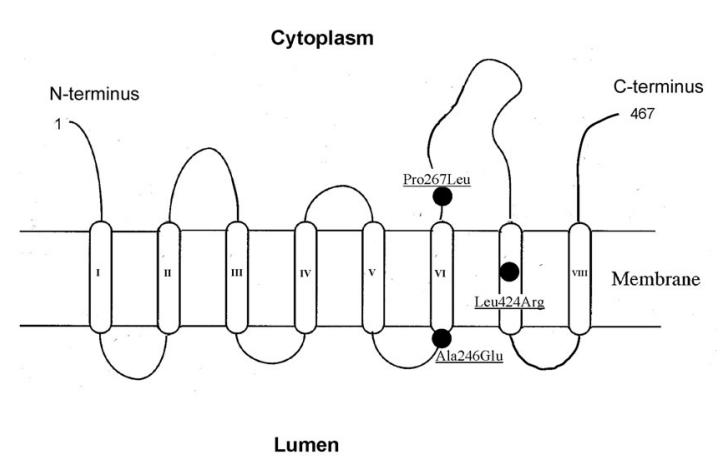

Figure 2. Putative structure of the Presenilin 1 gene product: a polytopic integral membrane protein with eight transmembrane domains.

Black dots indicate positions of the three identified mutations.

tance. The lack of APP and PS2 mutations in the analyzed subjects confirms their rare occurrence in patients with familial AD. The mutations are responsible for only a very small portion of familial AD. To gain better knowledge on the prevalence of the discussed mutations in the Polish population of $\mathrm{AD}$ patients, more extensive studies are required including a larger number of families with members from several generations. Besides, the vast majority of $\mathrm{AD}$ cases, over $90 \%$ of all patients, can be reffered to as sporadic $\mathrm{AD}$ with a negative family history of the disease and complex (multifactoral) inheritance. The genetic background of sporadic $\mathrm{AD}$ is still unknown and should be explained as soon as possible to allow the development of new genetic risk profiling strategies.

\section{R E F E R E N C E S}

Campion D, Dumanchin C, Hannequin D, Dubois B, Belliard S, Puel M, Thomas-Anterion C, Michon A, Martin C, Charbonnier F, Raux G, Camuzat A, Penet C, Mesnage V, Martinez M, Clerget-Darpoux F, Brice A, Frebourg T. (1999) Early-onset autosomal dominant Alzheimer's disease: prevalence, genetic heterogeneity, and muta- tion spectrum. Am J Hum Genet.; 65: 664-70.

Citron M, Oltersdorf T, Haass C, McConlogue L, Hung AY, Seubert P, Vigo-Pelfrey C, Lieberburg I, Selkoe DJ. (1992) Mutation of the $\beta$-amyloid precursor protein in familial Alzheimer's disease increases $\beta$-protein production. Nature.; 360: 672-4.

Cruts M, van Duijn CM, Backhovens H, Van den Broeck M, Wehnert A, Serneels S, Sherrington R, Hutton M, Hardy J, St George-Hyslop PH, Hofman A, Van Broeckhoven C. (1998) Estimation of the genetic contribution of presenilin-1 and -2 mutations in a population-based study of presenile Alzheimer disease. Hum Mol Genet.; 7: $43-51$.

Cruts M, Van Broeckhoven C. (1998) Presenilin mutations in Alzheimer's disease. Hum Mutat.; 11: 183-90.

Esler WP, Wolfe MS. (2001) A portrait of Alzheimer's secretases - new features and familiar faces. Science.; 293: 1449-54.

Hardy J, Higgins GA. (1992) Alzheimer's disease: the amyloid cascade hypothesis. Science.; 256: 184-5.

Jarret JT, Lansbury PT Jr. (1993) Seeding "one-dimensional crystallization" of amyloid: A pathogenic mechanism in Alzheimer's disease and scrapie? Cell.; 73: 1055-8.

Kamimura K, Tanahashi H, Yamanaka H, Takahashi K, Asada T, Tabira T. (1998) Familial Alzheimer's disease genes in Japanese. J Neurol Sci.; 160: 76-81.

Kowalska A. (2003) Amyloid precursor protein gene mutations responsible for early-onset autosomal dominant Alzheimer's disease. Folia Neuropathol.; 41: 43-8.

Kowalska A, Florczak J, Pruchnik-Wolinska D, Kraszewski A, Wender M. (1998)

Apolipoprotein E genotypes in sporadic early and late-onset Alzheimer's disease. Arch Immunol Therap Exp.; 46: 177-81.

Kowalska A, Florczak J, Pruchnik-Wolinska D, Hertmanowska H, Wender M. (1998) Screening for presenilin 1 gene mutations by PCR-SSCP analysis in patients with early-on- 
set Alzheimer's disease. Folia Neuropathol.; 36: $32-7$.

Kowalska A, Wender M. (1998) Mutations of presenilin genes and their role in pathogenesis of Alzheimer's disease. Neur Neurochir Pol.; 32: 1207-18.

Kovacs DM, Fausett HJ, Page KJ, Kim TW, Moir RD, Merriam DE, Hollister RD, Hallmark OG, Mancini R, Felsenstein KM, Hyman BT, Tanzi RE, Wasco W. (1996) Alzheimer-associated presenilin 1 and 2: neuronal expression in brain and localization to intracellular membranes in mammalian cells. Nat Med.; 2: 224-9.

Levitan D, Greenwald I. (1995) Facilitation of lin-12-mediated signalling by sel-12, a Caenorhabditis elegans. Proc Natl Acad Sci $U S$ A.; 93: 14940-4.

Levy-Lahad E, Wasco W, Poorkaj P, Romano DM, Oshima J, Pettingell WH, Yu CE, Jondro PD, Schmidt SD, Wang K, Crowley AC, Fu Y-H, Guenette SY, Galas D, Nemens E, Wijsman EM, Bird TD, Schellenberg GD, Tanzi RE. (1995) Candidate gene for the chromosome 1 familial Alzheimer's disease locus. Science.; 269: 973-7.

McKhann G, Drachman D, Folstein M. (1984) Clinical diagnosis of Alzheimer's disease: report of the NINCDS-ADRDA. Neurology.; 34: 939-44.

Niwa M, Sidrauski C, Kaufman RJ, Walter P. (1999) A role for presenilin 1 in nuclear accumulation of Ire1 fragments and induction of mammalian unfolded protein response. Cell.; 99: 691-702.

Rogaeva EA, Fafel KC, Song YQ, Medeiros H, Sato C, Liang Y, Richard E, Rogaev EI, Frommelt P, Sadovnick AD, Meschino W, Rockwood K, Boss MA, Mayeux R, St. George-Hyslop P. (2001) Screening for PS1 mutations in a referral-based series of $\mathrm{AD}$ cases: 21 novel mutations. Neurology.; 57: 621-5.

Saunders AM, Strittmatter WJ, Schmechel D, St George-Hyslop PH, Pericak-Vance MA, Joo SH, Rosi BL, Gusella JF, Crapper G, MacLachlan DR, Alberts MJ. (1993) Association of apolipoprotein $\mathrm{E}$ allele $\varepsilon 4$ with late-onset familial and sporadic Alzheimer's disease. Neurology.; 43: 1467-72.

Selkoe DJ. (1998) The cell biology of $\beta$-amyloid precursor protein and presenilin in Alzheimer's disease. Trends Cell Biol.; 8: 447-52.

Selkoe DJ, Podlisny MB. (2002) Deciphering the genetic basis of Alzheimer's disease. Annu Rev Genomics Hum Genet.; 3: 67-99.

Sherrington R, Rogaev EI, Liang Y, Rogaeva EA, Levesque G, Ikeda M, Chi H, Lin C, Li G, Holmn K, Tsuda T, Mar L, Foncin J-F, Bruni AC, Montesi MP, Sorbi S, Rainero I, Pinessi L, Nee L, Chumakov I, Pollen D, Brookes A, Sanseau P, Polinsky RJ, Wasco W, Da Silva HAR, Haines JL, Perical-Vance MA, Tanzi RE, Roses AS, Fraser JM, Rommens JM, St George-Hyslop PH. (1995) Cloning of a gene bearing missense mutations in early-onset familial Alzheimer's disease. Nature.; 375: 754-60.

Soriano S, Kang DE, Fu M, Pestell R, Chevallier N, Zheng K, Koo EH. (2001) Presenilin 1 negatively regulates $\beta$-catenin/ $\mathrm{T}$ cell factor/lymphoid enhancer factor-1 signaling independently of $\beta$-amyloid precursor protein and notch processing. $J$ Cell Biol.; 152: $785-94$.

Tanzi RE, Gusella JF, Walkins PC, Bruns GA, St George-Hyslop P, Van Keuren ML, Patterson D, Pagan S, Kurnit DM, Neve RL. (1987) Amyloid beta protein gene: cDNA, mRNA distribution, and genetic linkage near the Alzheimer locus. Science.; 235: 880-4.

Tanzi RE, Vaula G, Romano DM, Mortilla M, Huang TL, Tupler RG, Wasco W, Hyman BT, Haines JL, Jenkins BJ, Kalaitsidaki M, Warren AC, McInnis MC, Antonarakis SE, Karlinsky H, Percy ME, Connor L, Growdon J, Crapper-Mclachlan DR, Gusella JF, St George-Hyslop PH. (1992) Assessment of amyloid $\beta$-protein precursor gene mutations in a large set of familial and sporadic Alzheimer disease cases. Am J Hum Genet.; 51: $273-82$.

Van Broeckhoven C. (1995) Presenilins and Alzheimer's disease. Nat Genet.; 11: 230-2. 
Wenham PR, Price WH, Blandell G. (1991) Apolipoprotein E genotyping by one-stage PCR. Lancet.; 337: 1158-9.

Wragg M, Hutton M, Talbot C. (1996) Genetic association between intronic polymorphism in presenilin 1 gene and late-onset Alzheimer's disease. Alzheimer's disease collaborative group. Lancet.; 347: 509-12. 